\title{
Model Peningkatan Daya Saing Kopi Robusta Bagi Petani Di Kabupaten Bondowoso
}

\section{Model Of Increasing The Competitiveness Of Robusta Coffee In Bondowoso Regency}

\author{
Teguh Hari Santosa, Oktarina, Danu Indra Wardhana \\ Universitas Muhammadiyah Jember \\ teguh_hs66@yahoo.com
}

\begin{abstract}
ABSTRAK
Daya saing kopi rakyat dari masyarakat pinggiran hutan umumnya rendah yang berakibat pada lemahnya ekonomi masyarakat. Upaya peningkatan daya saing kopi rakyat tersebut akan memperkokoh ekonomi masyarakat melalui perbaikan teknologi budidaya, pengolahan pasca panen, struktur industri dan kondisi permintaan terhadap kopi rakyat. Tujuan penelitian ini adalah ingin mengetahui daya saiang kopi robusta dikabupaten bondowoso. Untuk mencapai tujuan tersebut menggunakan metode survei. Penelitian ini telah dilakukan di Kecamatan Sumber Wringin, Kabupaten Bondowoso selama 6 bulan pada tahun 2020. Hasil penelitian menunjukkan bahwa: daya saing kompetitif dan komparatif kopi rakyat hasil olah kering adalah tinggi yang ditunjukkan dengan nilai PCR 0,4261 dan nilai DRCR 0,4397. Kopi olah basah juga mempunyai daya saing kompetitif tinggi dengan nilai PCR 0,3679, namun daya saing komparatif cukup tinggi dengan nilai DRCR 0,5135. Meskipun daya saing kompetitif dan komparatif tinggi, namun keuntungan rata-rata per hektar kopi rakyat olah kering hanya sebesar Rp 743.681/ha/bulan lebih kecil dari UMR Kabupaten Bondowoso dan memberikan kontribusi kepada pendapatan keluarga sebesar 33,96\%. Sedangkan kopi olah basah meskipun mempunyai daya saing komparatif dengan kategori cukup tinggi namun keuntungannya lebih tinggi, yaitu Rp 1.483.742/ha/tahun dan mempunyai kontribusi 48,05\% terhadap pendapatan keluarga. Terdapat enam sarana produksi yang diperlukan untuk meningkatkan daya saing kopi rakyat, yaitu sumberdaya manusia, teknologi, modal, bahan baku, mesin dan pasar.

Kata kunci: kopi rakyat; daya saing kompetitif; daya saing komparatif
\end{abstract}

\section{ABSTRACT}

Smallholder cooffee was often identically with low productivity quality, and so was it's competitiveness. Because of that an effort was needed to increase the competitiveness of smallholder cooffee. This research was purposed for(1) knowing the competitive-ness of smallholder cooffee;(2)knowing the contribution of profit of smallholder cooffee to familiy's income; and (3)making a model of increasing the competitiveness of smallholder coffee at forest pheripheral area. Research used descriptive analitic methode, PCR and DRCR approach for measuring competitvef and comparatvef advantage and profit analysis. The result showed that: (1) Based on PCR and DRCR approach, all category of farmer has high competitve advantage and middle comparatvef advantage. The PCR of farmer wthout group was 0,39, farmer with dry process methode 0,44 and farmer with wet process methode 0,40. The DRCR was 0,66 for farmer wthout group, 0,5 for farmer with dry process methode and for farmer with wet process methode was 0,58; (2) The profit of farmer wthout group was lowest (Rp 6.489.879/ha/year), farmer with dry process methode was Rp 7.577.758/halyear and farmer with wet process methode was Rp13.023.460/ha/year. Further more the contribution to family income was 58,03\% for farmer wthout group,43,64\% for farmer with dry process methode and 49,64\% for farmer with wet process methode; (3)supporting of many institution and farmer's strong will to get better was needed for handling the six actual weaknessess and increasing the competitiveness of smallholder coffee at forest pheripheral

Key words: small holder coffee; competitive advantage; comparative advantage

\section{PENDAHULUAN}

Kopi rakyat sebagai salah satu komoditas nasional memiliki potensi daya saing yang dapat ditingkatkan melalui profitabilitas dan pangsa pasarnya. Faktor pemicu daya saing terdiri dari teknologi, produktivitas, input dan biaya, struktur industri dan kondisi permintaan (Rahman dkk., 2007). Upaya peningkatan daya saing kopi rakyat tersebut akan memperkokoh ekonomi masyarakat secara nasional melalui perbaikan teknologi budidaya (meliputi perbaikan produktivitas, mutu, input dan biaya), teknologi pengolahan pasca panen, struktur industri dan kondisi permintaan kopi rakyat.

Rata-rata areal kopi rakyat dari masyarakat pinggiran hutan di beberapa kabupaten di Indonesia seluas 4.911 ha (29 $\%)$ dari rata-rata perkebunan kopi di tiap kabupaten di Indonesia (16.882 ha). Rata-rata skala usaha kopi rakyat tersebut antara 1 - 
2 ha (BPS, 2011), namun kopi rakyat mempunyai keunikan rasa dan alami (kopi organik). Fokus kajian yang dipilih dalam penelitian ini yaitu upaya peningkatan daya saing kopi rakyat dari masyarakat pinggiran hutan dengan melibatkan berbagai institusi yang terkait (perguruan tinggi, balai penelitian, Perhutani, Dinas Kehutanan, Disperindag, LSM dan lainnya). Hal ini berpegangan pada social forestry yang sudah menjadi komitmen nasional dan kehendak politik pemerintah Indonesia (2 Juli 2003) dan UU No. 41 tahun 1999 tentang kehutanan bahwa pembangunan kehutanan harus diarahkan pada potensi sumberdaya hutan dan berbasis pada pemberdayaan masyarakat yang mengutamakan keunggulan produk lokal (local specific) yang kompetitif dan memperhatikan teknologi yang berdaya saing tinggi.

Hasil penelitian sebelumnya oleh Prayuginingsih dkk. (2007-2008) dan Santosa dkk (2011-2012) menemukan bahwa mutu dan produktivitas kopi rakyat umumnya rendah, penyebabnya antara lain: (a) teknologi budidaya dan pengolahan pasca panen belum sesuai dengan standar Puslit Kopi dan Kakao Indonesia; (b) penurunan kesuburan dan kualitas tanah; dan (c) lemahnya pengawasan kualitas di setiap tahap produksi sejak tanam, pengolahan hingga tata niaga kopi. Hal ini berakibat pada lemahnya ekonomi petani di pinggiran hutan dan mengancam upaya konservasi hutan, karena memicu keinginan mereka untuk merambah hutan. Tujuan penelitian ini adalah ingin mengetahui daya saiang kopi robusta dikabupaten bondowoso.

\section{METODE PENELITIAN}

Pendekatan yang digunakan dalam penelitian ini adalah pendekatan partisipatif, juga dilakukan upaya consciousness raising atau peningkatan penyadaran, peningkatan pengetahuan dan keterampilan dari penyampaian informasi, pelatihan dan advokasi dengan mempergunakan pendekatan pembangunan masyarakat melalui pelaksanaan pembelajaran sosial. Mengingat jenis kegiatan penelitian adalah terapan maka mulai digunakan metode
Survei yang mendalam dengan prinsip "berperan setara dan berbuat bersama" antara peneliti dan responden, dengan cara peneliti berada di tengah kehidupan responden dan merupakan bagian dari kehidupan mereka.

Penelitain ini dilakukan selama 6 bulan (Januari sampai Juli 2020. dan lokasi penelitian di Kecamatan Sumber Wringin, Kabupaten Bondowoso. Penentuan sampel (responden) dilakukan dengan stratified random sampling atau acak bertingkat, mengingat bahwa rumah tangga yang tinggal di pinggiran hutan sebagai populasi terdiri dari kelompok yang cukup heterogen. Tahapan pemilihan responden adalah sebagai berikut : (1) mengadakan stratifikasi populasi, yaitu mengklasifikasikan populasi menjadi kelompok-kelompok yang homogen dilihat dari jenis pekerjaan dan aktivitas ekonominya; (2) pemilihan responden dilakukan setelah memperoleh stratifikasi populasi, yakni masing-masing strata diambil 140 orang dikecamatan Sumber wringin, secara random.

Sumber data dalam penelitian ini dikelompokkan berdasarkan macam data (meliputi data primer dan sekunder). Sumber data primer diperoleh dari wawancara dan pengamatan langsung di lapangan. Sumber data sekunder diperoleh dari instansi terkait. Teknik pengumpulan data dalam penelitian ini selain menggunakan metode Participatory Rural Appraisal (PRA) dan Focus Group Discussion (FGD), juga menggunakan metode Rapid Rural Apprasial (RRA), Indept Interview dan Survey. Teknik analisis data menggunakan analisis kuantitatif dan kualitatif. Analisis kuantitatif terkait dengan daya saing kopi rakyat didekati dengan analisis keunggulan komparatif dan kompetitif dengan perhitungan nilai DRCR (Domestic Resources Cost Ratio) dan PCR (Private Cost Ratio) (Agustian, 2007).

Analisis kualitatif yang dipilih adalah analisis fenomenologis dan pola kecenderungan dilakukan sepanjang rentang waktu penelitian dengan menggunakan analisis FGD, RRA, PRA. 
HASIL PENELITIAN

Daya Saing Kopi Rakyat

Tabel 1. Policy Analysis Matrix per hektar Usahatani Kopi Rakyat di Lokasi Penelitian Tahun 2020 (dalam rupiah)

\begin{tabular}{cccccc}
\hline $\begin{array}{c}\text { Jenis } \\
\text { Pengolahan }\end{array}$ & Uraian & $\begin{array}{c}\text { Revenue } \\
\text { Tradeable }\end{array}$ & $\begin{array}{c}\text { Input } \\
\text { Tradeable }\end{array}$ & $\begin{array}{c}\text { Input } \\
\text { Untradeable }\end{array}$ & Profit \\
\hline Olah kering & Harga privat & $16.381 .685,32$ & $758.719,36$ & $6.657 .594,46$ & $8.965 .371,50$ \\
& Harga sosial & $18.762 .343,74$ & $1.150 .257,72$ & $7.744 .561,20$ & $9.867 .524,83$ \\
& Divergensi & $(2.380 .658,42)$ & $(391.538,36)$ & $(1.086 .966,74)$ & $(902.153,33)$ \\
Olah basah & & & & \\
& Harga privat & $29.735 .333,33$ & $1.646 .319,44$ & $10.335 .043,18$ & $17.753 .970,70$ \\
& Harga sosial & $25.725 .649,70$ & $2.312 .430,60$ & $12.022 .988,57$ & $11.390 .230,53$ \\
& Divergensi & $4.009 .683,63$ & $(681.228,45)$ & $(1.687 .945,38)$ & $.378 .857,46$ \\
\hline
\end{tabular}

Sumber: data primer diolah (2012)

Berdasar Tabel 1. maka diketahui daya saing kopi rakyat di lokasi penelitian sebagai berikut:

a. Daya Saing Kompetitif

Kopi rakyat, baik olah kering maupun basah, memiliki daya saing kompetitif yang tinggi karena keduanya memiliki nilai PCR < 1 , namun kopi olah basah mempunyai daya saing lebih tinggi karena penggunaan faktor domestik lebih effisien dalam menghasilkan nilai tambah. Nilai PCR olah basah sebesar 0,3679 menujukkan besarnya biaya faktor produksi domestik yang diperlukan untuk menghasilkan nilai tambah sebesar satu satuan, sedangkan kopi olah kering membutuhkan biaya yang lebih besar, yaitu sebesar 0,4261.

Tabel 2. Nilai PCR dan DRCR Kopi Rakyat di Lokasi Penelitian tahun 2020

\begin{tabular}{lcccc}
\hline \multirow{2}{*}{ Jenis Pengolahan } & \multicolumn{3}{c}{ PCR } & DRCR \\
\cline { 2 - 5 } & Nilai & Kriteria daya saing & Nilai & Kriteria daya saing \\
\hline Olah Kering & 0,4261 & tinggi & 0,4397 & tinggi \\
Olah Basah & 0,3679 & Daya saing tinggi & 0,5135 & Daaya saing cukup tinggi \\
\hline
\end{tabular}

Sumber: data primer diolah (2012)

Analisis PCR $(0,3679)$ dan DRCR $(0,5135)$, menujukkan hasil kopi rakyat dengan olah basah sehingga tergolong daya saingnya tergoling cukup tinggi.

b. Daya Saing Komparatiif

Nilai DRCR menujukkan besarnya biaya faktor produksi domestik yang diperlukan untuk menghasilkan tambahan devisa sebesar satu satuan. Nilai DRCR kopi olah kering $(0,4397)$ ternyata sedikit lebih rendah dibanding olah basah $(0,5135)$, yang menunjukkan bahwa olah kering memerlukan biaya faktor produksi domestik yang lebih rendah untuk memperoleh tambahan satu satuan devisa. Meskipun demikian kopi olah basah masih mempunyai daya saing komparatif yang cukup tinggi karena nilai DRCR $<1$ sehingga masih menguntungkan apabila melakukan ekspor. Selain itu divergensi penerimaan jual kopi olah basah https://doi.org/10.32528/agribest.v4i2.3405 menunjukkan nilai positif yang menunjukkan bahwa harga jual di tingkat petani lebih tinggi dibanding harga rata-rata kopi di pasar ekspor, yang menunjukkan bahwa kopi rakyat mempunyai daya saing yang tinggi.

Mendasar pada hasil analisis maka terlihat bahwa kopi rakyat, baik olah kering dan basah, mempunyai daya saing kompetitif dan komparatif yang tinggi.

Selain daya saing, upaya peningkatan perekonomian petani kopi rakyat juga harus disertai dengan peningkatan pendapatan petani, karena dengan pendapatan tersebut petani dapat memenuhi berbagai kebutuhan hidup dan mensejahterakan keluarga.

\section{Keuntungan Usahatani Kopi Rakyat di Kabupaten Bondowoso}

Hasil analisis menunjukkan bahwa keuntungan usahatani kopi rakyat olah basah (Rp17.753.970/ha/tahun) hampir dua kali 
lipat lebih tinggi daripada olah kering yang hanya Rp 8.965.371/ha/tahun (Tabel 5.4). Faktor utama yang menyebabkan perbedaan keuntungan ini adalah perbedaan penerimaan yang disebabkan perbedaan produktivitas dan Tabel 3. Struktur Biaya dan Keuntungan per ha Us Privat

\begin{tabular}{|c|c|c|c|c|c|c|}
\hline Uraian & & lah Ker & & & & h Basah \\
\hline $\begin{array}{c}\text { Revenue } \\
\text { tradeable }\end{array}$ & $(\mathbf{R p})$ & & 16.381.685,32 & & & 29.735.333,33 \\
\hline Input Tradeable & (Rp) & $\%$ & & (Rp) & $\%$ & \\
\hline a. Pupuk & $748.682,65$ & 10,10 & & $1.646 .319,44$ & 14,12 & \\
\hline b. Obat-obatan & $10.036,71$ & 0,14 & & 0,00 & - & \\
\hline Jumlah & $758.719,36$ & 10,23 & & $1.646 .319,44$ & 14,12 & \\
\hline $\begin{array}{c}\text { Input } \\
\text { Untradeable }\end{array}$ & (Rp) & $\%$ & & (Rp) & $\%$ & \\
\hline a. Pupuk kandang & $190.978,49$ & 2,58 & & $686.666,67$ & 5,89 & \\
\hline b. Tenaga kerja & $2.533 .616,68$ & 34,16 & & $4.340 .000,33$ & 37,23 & \\
\hline c. Pengolahan & $1.157 .409,00$ & 15,61 & & $2.372 .395,83$ & 20,35 & \\
\hline d. Transportasi & $55.349,00$ & 0,75 & & $58.900,00$ & 0,51 & \\
\hline $\begin{array}{l}\text { e. Bunga Modal } \\
\text { Kerja }\end{array}$ & $571.009,28$ & 7,70 & & 1.107.080,68 & 9,50 & \\
\hline f. Sewa lahan & $2.149 .232,00$ & 28,98 & & $1.770 .000,00$ & 15,18 & \\
\hline Jumlah & $6.657 .594,45$ & 89,77 & & $10.335 .043,52$ & 88,66 & \\
\hline Biaya Total & $(\mathbf{R p})$ & & 7.416.313,81 & & & 11.981.362,96 \\
\hline Profit & (Rp) & & 8.965.371,51 & - & & 17.753.970,37 \\
\hline
\end{tabular}

Selain produktivitas kopi oleh basah juga menghasilkan kualitas kopi yang lebih baik dibanding olah kering sehingga memenuhi standar kualitas ekspor dan mempunyai harga jual tinggi. Harga jual produk merupakan salah satu motivasi petani untuk menerapkan teknik budidaya serta pananganan panen dan pasca panen dengan baik agar dapat memperoleh produk yang berkualitas dan mempunyai produktivitas tinggi. Konsekuensi dari tingginya produktivitas adalah semakin besarnya biaya tenaga kerja panen, pengolahan pasca panen, transportasi dan biaya bunga modal kerja.

Teknik budidaya yang dapat dinilai baik dari petani olah basah adalah tidak digunakannya pestisida sama sekali, penggunaan pupuk kimia sebesar Rp 1.646.319 serta penggunaan pupuk organik/kompos yang lebih banyak.

Biaya pemupukan per ha kopi olah basah lebih besar dibanding olah kering, baik secara nominal maupun proporsional. Proporsi biaya pemupukan kopi olah basah mencapai $14,12 \%$ dari total biaya, sedangkan https://doi.org/10.32528/agribest.v4i2.3405 harga jual. Produktivitas kopi olah basah adalah $1.221,53 \mathrm{~kg} / \mathrm{ha}$, sedikit lebih rendah dari produktivitas rata-rata tertinggi yang mungkin dicapai sebesar $1.500 \mathrm{~kg} / \mathrm{ha}$, sedangkan olah kering hanya $890,38 \mathrm{~kg} / \mathrm{ha}$.

Kopi Rakyat di Lokasi Penelitian pada Harga 
UMR Kabupaten Jember, yaitu Rp 1.483 .742

dengan kontribusi terhadap pendapatan keluarga sebesar 48,05\% (Tabel 5.6). Pendapatan kebanyakan keluarga di pinggiran hutan berasal dari keuntungan

Tabel . Struktur Pendapatan Keluarga Petani Kopi Rakyat per ha Lahan di Lokasi Penelitian

\begin{tabular}{llll}
\hline \multicolumn{1}{c}{ Uraian } & \multicolumn{1}{c}{ Satuan } & \multicolumn{1}{c}{ Olah Kering } & \multicolumn{1}{c}{ Olah Basah } \\
\hline Rata-rata penguasaan lahan & ha & 2,01 & 1,13 \\
Keuntungan kopi/unit/tahun & Rp/unit/tahun & 20.241 .766 & 17.983 .776 \\
Keuntungan kopi/unit/bulan & Rp/unit/bulan & 1.686 .814 & 1.498 .648 \\
Keuntungan kopi/ha/tahun & Rp/ha/tahun & 8.924 .173 & 17.804 .906 \\
Keuntungan kopi/ha/bulan & Rp/ha/bulan & 743.681 & 1.483 .742 \\
Pendapatan lain total/bulan & Rp/bulan & 1.446 .103 & 1.589 .063 \\
Pendapatan lain+kopi/bulan & Rp/bulan & 2.189 .784 & 3.087 .710 \\
Kontribusi kopi & $\%$ & 33,96 & 48,05 \\
\hline
\end{tabular}

usahatani kopi, tanaman sela dan dari pekerjaan lainnya seperti berdagang, buruh, mekanik, patani tanaman pangan dan lainlain.

Sumber: data primer diolah (2020)

Mendasar pada angka kontribusi keuntungan kopi rakyat, baik olah kering maupun basah, yang kurang dari $50 \%$ maka dapat dikatakan bahwa bertani kopi pada luasan lahan satu hektar belum mampu menutup seluruh kebutuhan keluarga petani kopi. Olah karena itu meskipun sudah mempunyai daya saing tinggi, masih diperlukan berbagai upaya untuk meningkatkan keuntungan usahatani kopi rakyat agar memberikan kontribusi yang lebih besar dalam pendapatan keluarga petani kopi. Petani kopi di pinggiran hutan yang lebih sejahtera dan mempunyai pendapatan yang lebih tinggi akan memberikan economic multiplyer effect kepada masyarakat sekitarnya sehingga secara keseluruhan akan memperkokoh perekonomian masayarakat pinggiran hutan.

\section{KESIMPULAN DAN SARAN Kesimpulan}

Daya saing kompetitif dan komparatif kopi rakyat di Kabupaten Bondowoso dengan hasil olah kering adalah tinggi yang ditunjukkan dengan nilai PCR 0,4261 dan nilai DRCR 0,4397. Kopi olah basah juga mempunyai daya saing kompetitif tinggi dengan nilai PCR 0,3679, namun daya saing komparatif cukup tinggi dengan nilai DRCR 0,5135. Meskipun daya saing kompetitif dan komparatif tinggi, namun keuntungan rata-rata per hektar kopi rakyat olah kering hanya sebesar Rp 743.681/ha/bulan lebih kecil dari UMR
Kabupaten Bondowoso dan memberikan kontribusi kepada pendapatan keluarga sebesar 33,96\%. Sedangkan kopi olah basah meskipun mempunyai daya saing komparatif dengan kategori cukup tinggi namun keuntungannya lebih tinggi, yaitu Rp 1.483.742/ha/tahun dan mempunyai kontribusi $48,05 \%$ terhadap pendapatan keluarga. Terdapat enam sarana produksi yang diperlukan untuk meningkatkan daya saing kopi rakyat, yaitu sumberdaya manusia, teknologi, modal, bahan baku, mesin dan pasar.

\section{Saran}

1.Saran kepada Dinas Pertanian yaitu perlu memperhatikan penyuluhan terus menerus kepada petani kopi rakyat agar kualitas kopi terus meningkat, sehinnga akan memperoleh harga kopi yang tinggi.

2. Saran kepada petani kopi rakyat agar menjaga kerjasama antar anggota kelpmpok tani agar kualitas kopi tetap baik, dan harga kopi tetap tinggi.

\section{Ucapan Terima Kasih}

Ucapan terima kasih yang setinggitingginya kami ucapkan kepada Pimpinan UM Jember yang telah mendanai penelitian ini. 


\section{DAFTAR PUSTAKA}

Agustian, A. 2007. Daya Saing dan Profil Produk Agroindustri Skala Kecil (Kajian di Propinsi Lampung). Prosiding Seminar Nasional Teknologi Inovatif Pasca Panen untuk Pengembangan Agroindustri Berbasis Pertanian. Balai Besar Penelitian dan Pengembangan Pascapanen Pertanian. Hal. 979 989.

BPS, 2011. Jember dalam Angka. Kerjasama Badan Perencana Pembangunan Kabupaten Jember dengan BPS Kabupaten Jember.

Direktorat Jenderal Bina Produksi Perkebunan. 2007. Kebijakan dan Strategi Pembangunan Perkopian Nasional. Warta Pusat Penelitian Kopi dan Kakao, 19 (1): 1 - 8.

Kustiari, R. 2007. Perkembangan Pasar kopi Dunia dan Implikasinya bagi Indonesia. Pusat Analisis Sosial Ekonomi dan Kebijakan Pertanian. Hal. $43-55$.

Monke, E. A. and S. R. Parson. 2006. The Policy Analysis Matrix for Agriculture Development. Cornell University Press. Ithaca and London.

Prayuginingsih, H.; F. Kuswantoro; T.H. Santosa, N.S. Rizal dan A.B. Susetyo. 2007-2008. Analisis Keuntungan Usahatani Kopi Arabika Organik di Kabupaten Aceh Tengah Propinsi Aceh. Fakultas Pertanian. Universitas Muhammadiyah Jember. Jurnal Agritrop (Jurnal Ilmu-ilmu Pertanian). Vol. 3, No.2, 2008.
Rahman, R., A. Nuhung, dan M. Rachmat. 2007. Studi Pengembangan Sistem Agribisnis Perkebunan Rakyat dalam Perspektif Globalisasi Ekonomi. Makalah Seminar Hasil Penelitian. Puslitbang Sosek Pertanian. Bogor.

Santosa, T.H.; H. Prayuginingsih; dan N.S. Rizal. 2009-2010. Konservasi Hutan Lindung dan PHBM (Pengelolaan Hutan Bersama Masyarakat) antara Perhutani Kabupaten Jember dan Bondowoso Dengan Masyarakat Pinggiran Hutan. Jurnal Agritrop (Jurnal Ilmu-ilmu Pertanian). Vol. 5, No.2, 2010.

Santosa, T.H.; H. Prayuginingsih; dan N.S. Rizal. 2011-2012. Analisis Mutu dan Produktivitas Kopi Rakyat pada Masyarakat Pinggiran Hutan di Kecamatan Ledokombo, Jember dan Kecamatan Grujugan, Kabupaten Bondowoso. Jurnal Agritrop (Jurnal Ilmu-ilmu Pertanian). Vol. 7, No.1, 2012.

Simatupang, P. 2008. Koordinasi Vertikal Sebagai Strategi Untuk Meningkatkan Daya Saing dan Pendapatan dalam Era Globalisassi Ekonomi (kasus Agribisnis Kopi). Pusat Penelitian Sosial Ekonomi Pertanian, Badan Penelitian dan Pengembangan Pertanian, Departemen Pertanian, Bogor.

Soetriono. 2012. http://irtusss.blogspot.com/2011/02/a nalisis-finansial-dan-ekonomi. html. 